\title{
La narrativa de Harold Foster: más allá de la grandeza del ilustrador
}

\author{
Marina Segarra García
}

Marina Segarra García (Valencia, 1958) es Licenciada en Historia del Arte por la Universitat de València (UV) y Licenciada y Doctora en Bellas Artes por la Universitat Politècnica de València (UPV), en donde es profesora en la Titulación de Comunicación Audiovisual (UPV-Campus de Gandía), titulación de la que fue ponente de su plan de estudios y responsable de su implantación y dirección académica. Ha impartido diversos cursos en Máster y Doctorado y dirigido Proyectos de Innovación Educativa en Nuevas Metodologías Docentes y en Investigación Aplicada al Campo de la Recuperación Patrimonial de las Historietas. A nivel profesional ha sido editora y directora de la Revista de historietas "Marca Acme" (UPV,1986) y de los cuadernillos "Acme Travels" (Producciones Acme, 1988) y ha trabajado como guionista en el Comic-Book "Opium” de Daniel Torres (Norma Editorial,1989), en terreno audiovisual, ha sido también directora, guionista, realizadora y montadora de diversas piezas audiovisuales, exhibidas tanto en televisión local como nacional y en distintos festivales. Actualmente también es la directora académica de la Revista Audiovisual On-Line "La Mirada Cautiva" (http://www.lamiradacautiva.webs.upv.es) y de las Jornadas Miguel Silva de Type in Motion: "Un Tipo Inquieto" (patrocinadas por ESAT).

Fecha de recepción: 9 de junio de 2015

Fecha de aceptación definitiva: 24 de julio de 2015 


\title{
Resumen
}

En este artículo tratamos de reflexionar sobre las técnicas narrativas utilizadas por Harold Foster para transmitir la trama a su lector. Clarificar algo que sigue siendo un tema de debate: la ausencia de bocadillos en toda la saga de El Principe Valiente. Foster utilizará la voz de un narrador omnisciente en todas las viñetas, hecho por el que se tilda de narrador anclado en técnicas obsoletas. Queremos demostrar sucintamente lo esencial del medio y como Foster hace uso de ello y aproximarnos también a los motivos que tuvo para abordar sus relatos de estas aventuras como lo hizo.

Palabras clave: Harold Foster, bocadillos, técnicas narrativas, narrador omnisciente, cooperación lectora.

\begin{abstract}
In this article we try to reflect upon the narrative techniques used by Harold Foster to transmit the plot to his readers. We try to clarify something that remains a topic of debate: The absence of speech bubble throughout the saga of Prince Valiant. Foster used the voice of an omniscient narrator in all the frames, a fact which is labeled by Harold Foster as a narrator anchored in obsolete techniques. We briefly demonstrate how essential the media is and how Foster uses it. We also examine the reasons he had for tackling the narratives of these adventures the way he did.

Key words: Harold Foster, Balloons, Narrative Technics, Omniscient Narrator, Reading Cooperation
\end{abstract}

\section{Cita Bibliográfica}

Segarra García, M. "La narrativa de Harold Foster: más allá de la grandeza del ilustrador", en CuCo, Cuadernos de cómic n. ${ }^{\circ} 4$ (2015), pp. 35-58 
Mientras todo el mundo al evocar el trabajo de Harold Foster centra su atención en la grandiosidad y maestría de su dibujo, hasta el punto de considerar al autor de Valiant como el Principe de los ilustradores ${ }^{1}$ del siglo $\mathrm{xx}$, el reto de las siguientes líneas es reflexionar sobre lo que muchos, al comentar su obra, eluden a menudo o pasan de puntillas: la técnica narrativa o métodos utilizados por Foster para transmitir la trama a su lector. La narrativa de un Foster, narrador de aventuras gráficas, en un momento de la ya avanzada década de los años 30, cuando el lenguaje de la historieta era ya un hecho y estaban prácticamente definidas sus estrategias y los recursos básicos de expresión narrativa ${ }^{2}$ o todo aquello que lo había convertido en un medio, si bien aún joven, distinto, peculiar e inconfundible.

A principios de 1937, fecha en que vio la luz la primera entrega de El Principe Valiente, era pues un tiempo en el que había quedado establecido como un importante elemento de identidad del cómic la utilización del bocadillo como metáfora de los diálogos y con él, los múltiples recursos para la evocación gráfica de las distintas voces de los personajes en el papel, del tono y modulación de palabras y pensamientos de sus protagonistas y hacer así que el relato "transcurra" ante la mirada del lector sin necesitar un explicador externo que le comente lo que sucede ${ }^{3}$ - tal y como ocurría en Aleluyas o Aucas - y por tanto como algo no solo singular, sino inherente y definitorio del medio.

Hal Foster, por el contrario, seguirá construyendo el relato mediante una omnisciente presencia de la voz del narrador en todas las viñetas, ${ }^{4}$ a través de esas letras impresas inscritas en cada uno de los planos — si bien meditadas selecciones y representaciones de instantes precisos y evocadores-, algo que sin duda más de un autor lo ha referido como una persistencia del sistema de narración primitivo, mas propio y cercano a las protohistorietas o a los elegantes libros ilustrados de principios de siglo, tal y como lo expresa Mark Schultz: ${ }^{5}$ Con mucha frecuencia leemos críticas poco halagüeñas sobre las tiras de Tarzán o El Príncipe Valiente que las tildan de "textos ilustrados" en contraposición a narraciones secuenciales empleando el lenguaje exclusivo de redacción de los cómics. Si bien es cierto que su predilección por evitar los bocadillos de diálogo a favor de la cartela rectangular, así como la clásica construcción de sus viñetas, a menudo estáticas, acercan en gran medida su obra a los libros ilustrados tradicionales; no obstante, esto constituye tan solo rasgos superficiales de estilo que obviamente distraen la atención e impiden apreciar las características genuinas que ocultan. ${ }^{6}$

1 Apropiándome del nombre que da título a la interesante biografía sobre este autor escrita por Brian M. Kane: Hal Foster. Principe de ilustradores. Padre de las tiras de aventuras. Barcelona, Planeta DeAgostini, 2006.

2 Sin olvidar que todo lenguaje, por el hecho de serlo, está en continua evolución, buscando técnicas y recursos particulares para cada nueva historia a contar.

3 Cfr. Segarra, M. "La mirada del lector y el devenir del relato gráfico." En Quaderns de filología. Estudis de Comunicació, n. ${ }^{\circ} 3$ (2008), pp. 195-221.

${ }^{4}$ Lo que motiva los aún hoy frecuentes debates sobre si considerar o no su obra como historieta pura.

${ }^{5}$ Schultz, junto al dibujante Gary Gianni, fue desde el 21 de noviembre de 2004 el escritor de los guiones de El Príncipe Valiente, contratado por el King Features Syndicate para la edición contemporánea de la leyenda Artúrica. Schultz sucedió al escritor Cullen Murphy, hijo del dibujante John Cullen Murphy quién en estrecha colaboración con Foster, se haría cargo del dibujo de El Principe Valiente a partir del 23 de mayo de 1971, cuando una avanzada artritis impediría a Harold Foster realizar él mismo los dibujos. Cullen hijo, trabajó junto a ellos en los guiones, dejando la saga tras la muerte de su padre.

${ }^{6}$ Kane, Brian M. Op. Cit., p. 200. 
Para realizar una aproximación a esas características genuinas del trabajo narrativo que Foster concibió para la construcción de las historias épicas de su Principe Valiente ${ }^{7} y$ desentrañar las aportaciones de su particular sistema de relato, junto a su coherencia o no como técnica narrativa adecuada a la forma del medio historieta, lo primero que debemos observar es el acto de narración y advertir su efecto. Efecto no en cuanto al contenido argumental - lo relatado- ${ }^{8}$ sino en el modo como se nos da a conocer la historia de El Principe Valiente.

Frente a las críticas que tienden a separar la ilustración de las palabras del narrador diremos que por contra para un análisis de la narración, lo importante precisamente son las relaciones estructurales entre todos sus elementos expresivos, ya que la idea de estructura implica la de función.

\section{La UTILIZACIÓN DE LA VOZ DE UN NARRADOR OMNISCIENTE: UNA ELECCIÓN CONSCIENTE POR PARTE DE FOSTER.}

Empecemos por considerar las posibles motivaciones que pudo tener Foster para mantener esa voz de un narrador omnisciente, como uno de los ejes que estructuran su estrategia narrativa: un narrador externo a la historia y explícito y por tanto una voz que no está $n a-$
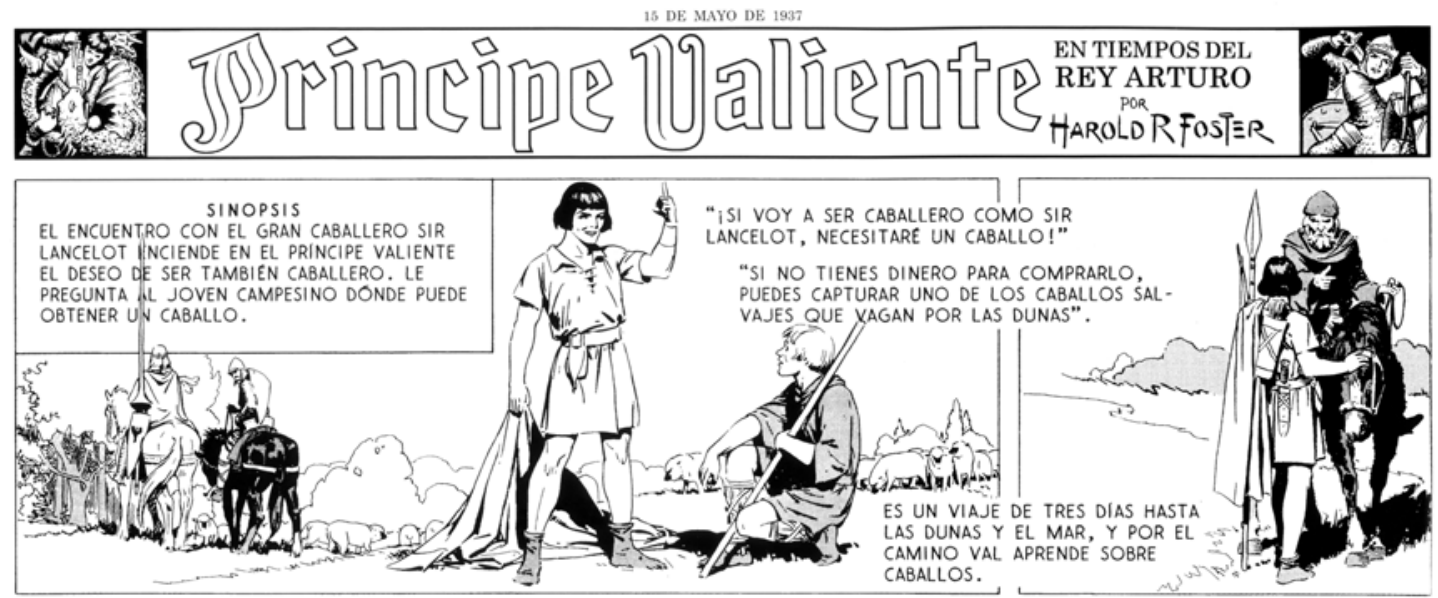

FIG. 1. Viñetas n. ${ }^{\circ} 1$ y 2 de la plancha n. ${ }^{\circ} 14$ (15-

V-37). Fuente: Príncipe Valiente Vol.1: 1937-1938

Manuel Caldas Ed. (2006). (C) King Features Syndicate, Inc.

\footnotetext{
7 Soy consciente de la imposibilidad de resolver, aquí y ahora, el reto impuesto por el tema elegido. No solo por la extensión desmesurada que cobraría su estudio, el propio volumen de la obra de Foster, las abundantes ediciones realizadas de la saga y la particular complejidad del asunto. Es por ello que he creído conveniente abordar un estilo de escritura en el que continuamente daré paso a la voz de otros autores, entrelazando mis palabras junto a otras muchas que irán apareciendo como citas directas, a veces algo extensas, pero seguro más enriquecedoras que su resumen, intentando de ese modo construir una reflexión coral y con un solo objetivo: considerar detenidamente algunos temas que creo se encuentran vinculados y no han sido referidos al tratar este tema, con voluntad de cambiar el rumbo de los debates.

${ }^{8}$ No es mi intención indagar la relación existente entre la historia de esta saga con su referente histórico, ni tampoco adentrarme en un análisis del género de aventuras y la verosimilitud.
} 
turalizada, al no pertenecer a ninguno de los personajes inmersos en los acontecimientos relatados. El narrador de Foster es una voz anónima (sobre la que deberíamos preguntarnos ¿quién habla?) que nos expone ciertas informaciones sustanciosas y "objetivas" y que sin duda refiere y remite sobre una "conciencia" que tiene el conocimiento de todo. Por el contrario la naturalización y el uso de los personajes como mediadores en el relato visual es lo que permite al lector acceder al conocimiento de lo que sucede "presenciándolo", pero a su vez, es también lo que consigue que el propio lector deje de ser consciente y olvide el artificio narrativo: pues para poder conocer la historia observa lo que está pasando, reconstruyendo, deduciendo y completando continuamente la información que se le muestra en cada viñeta - incluso el propio relato le obliga a menudo a realizar anticipos sobre lo que puede llegar a pasar (que serán gratificados o rechazados conforme avance la acción)—. ${ }^{9}$ El lector, de este modo, queda atrapado en la recreación y confección del propio relato y al participar en la reconstrucción de la historia contada, sin querer, pierde la noción de que aquello es un artificio.

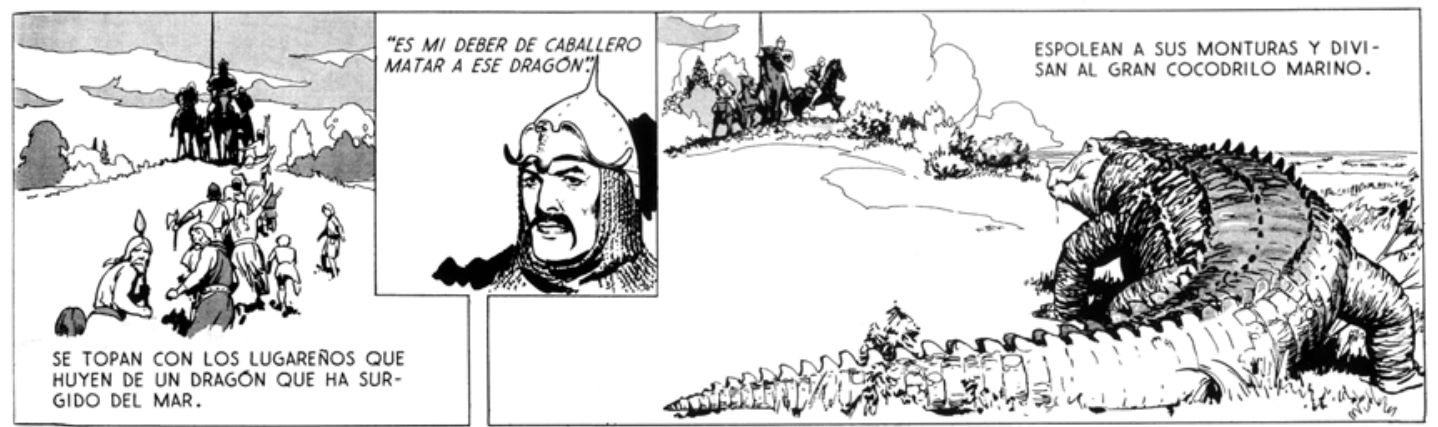

FIG. 2. Viñetas n.o 3, 4 y 5 de la plancha n.o 17 (6-V-37). Fuente: Principe Valiente Vol.1: 19371938 Manuel Caldas Ed. (2006). (C) King Features Syndicate, Inc.

No obstante debemos evidenciar que en el acto narrativo absolutamente todas las "voces", incluso las directas, aun estando "naturalizadas" por quedar vinculadas a los diferentes personajes participantes, son también estrategias narrativas, decisiones sobre la información que deben transmitir en ese preciso momento de la historia y por tanto todas ellas (narrador implícito, explícito y personajes) son un acuerdo, un pacto tácito, fruto de la convención narrativa. Rafael Marín ${ }^{10}$ escribe al respecto: "Si Foster hubiera utilizado bocadillos (y solo aparece un breve conato de bocadillo entre las viñetas 1 y 2 de la página 14) —vid. Fig. n. ${ }^{\circ}$ 1 - su dibujo se hubiera visto ensombrecido, la narración habría quedado lastrada e infan-

\footnotetext{
9 Vid. al respecto Eco, U. "El Lector Modelo", en Lector in fabula. La cooperación interpretativa en el texto narrativo. Barcelona, Lumen, 1993, pp.73-79, en donde el autor desarrolla un interesante análisis de esos mecanismos de cooperación — si bien para el texto literario - partiendo de la evidencia de que un texto siempre está incompleto, plagado de cosas "no dichas" y es el destinatario, su lector, quien lo actualiza dándole el significado real, completando así su contenido. Pero para ello todo debe de estar ya previsto desde el propio texto narrativo, gracias a complejas acciones expresivas que buscan apelar esa cooperación del lector, para que sea él quien interprete y reconstruya el verdadero sentido de lo dicho, reconstruyendo de este modo lo sucedido.

${ }^{10}$ Marín, R. Hal Foster. Una épica postromántica. Madrid, Ediciones Sins Entido. 2004, p.44.
} 


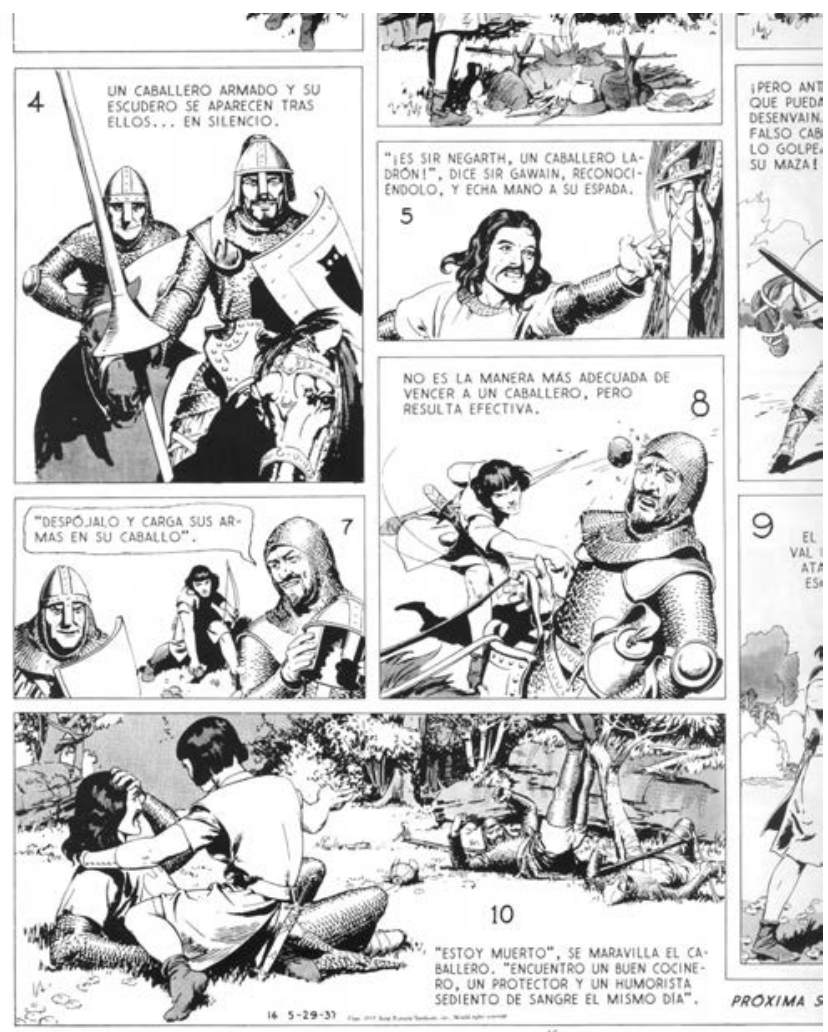

FIG. 3. Viñeta 7 de plancha n. ${ }^{\circ} 16$ (detalle). Fuente: Principe Valiente Vol.1: 1937-1938 Manuel Caldas Ed. (2006). C King Features Syndicate, Inc.

tilizada, y el aliento épico se habría perdido". Sin embargo es interesante observar como Foster utiliza el estilo directo en los diálogos sin ningún comentario del narrador con otro código, el del entrecomillado, en muchas más viñetas y planchas de las que comenta Marín, y a lo largo de toda la saga, algo que pasa totalmente desapercibido.

Aunque volveremos a tratar este tema más adelante, nuestro lector puede observar como existe esa locución directa del personaje a lo largo de todas las entregas de El Príncipe Valiente. Así y en esta primera época (1937-1938) la encontramos también en la plancha n. ${ }^{\circ}$ 17 (29-V-37) —vid. Fig. n. ${ }^{\circ}$ 2- o en las 20/24/26/40/41/etc. Hay que resaltar la extraña aparición de un bocadillo, como tal, en la viñeta 7 de plancha n. ${ }^{\circ} 16$-vid. Fig. n. ${ }^{\circ} 3$ - en donde las comillas han sido sustituidas por el código convencional del globo con apéndice y que como se puede ver distorsiona claramente el ecosistema narrativo-visual ideado por Foster. Es casi imposible precisar la autoría de este elemento - aunque se encuentre en la edición original-, en la medida que para el mundo editorial la rotulación original ha sido desde siempre un elemento poco o nada respetado.

Un caso espectacular sería la publicación en España de El Príncipe Valiente entre 1959 y 1960, a cargo de la Editorial Dólar dentro de su Colección Novelas Gráficas: Series Amarilla y 
Sepia y en donde, además de re-maquetar todas las planchas para adaptarlas a su formato de publicación, se crearon bocadillos para alojar los diálogos directos de los personajes.

De modo que si bien Hal Foster no hace un uso estricto de la convención y de las amplias posibilidades expresivas de los bocadillos, utiliza el entrecomillado bajo una función idéntica a ellos: como indicadores fonéticos y, como intentaremos demostrar, no es por estar anclado en una técnica narrativa obsoleta sino como fruto de una decisión como autor - más adelante abordaremos este asunto-: la de integrarlos bajo el mismo tratamiento estético que el del resto de letra impresa. ${ }^{11}$ Así y ante la ya clásica distinción entre diálogo indirecto [aquel que nos es referido también por la voz del narrador ["sí" - responde el caballeroo "(...)"-dice el rey Arturo-, etc.] y el directo — sin mediación alguna-, la historieta utiliza el globo o bocadillo como código y convención metafórico-visual para representar el diálogo directo de los personajes. Un código rico en modulaciones expresivas, gracias a las variaciones de su forma, a la cualidad de su trazado, a su grafismo y que al igual que su apéndice, cuya función es la de indicar la fuente de procedencia y la pertenencia de la locución, nos proponen matices de la locución de los personajes bien enriquecedores, matices tales como el volumen de la voz, el estado emocional del personaje, un pensamiento, etc. En sí, un importante y significativo contenedor de la representación naturalizada del diálogo directo. Foster, por el contrario, utiliza en mayor medida el diálogo indirecto pero también hace uso - como hemos podido ver-, de la voz directa de sus personajes, si bien en ocasiones muy concretas. En ese caso, el código del bocadillo ha sido sustituido por el de las comillas. Es cierto que el autor pierde con ello toda una serie de recursos expresivos asociados al código generalizado del bocadillo pero, rigurosamente, ambos casos son un sistema metafórico de "representación" de los diálogos en estilo directo.

\section{El conflicto de Foster-narrador y su resolución discursiva}

Tras la decisión de abandonar Tarzán, dejándola sin ni siquiera esperar a terminar el episodio, nos encontramos con un Foster ya maduro de 44 años, adiestrado en el arte del dibujo minucioso y descriptivo, que desea realizar una obra plenamente propia ${ }^{12}$ y hacerse cargo enteramente de la creación de todo un universo gráfico sin tener que depender de terceros, en su caso, de un proceso de adaptación y de encargo como lo era el del relato de E. R. Burroughs, Tarzan of the Apes. Pero al enfrentarse ante su propio acto de creación de esta gran historia y por tanto ante la definición de estrategias para narrar las aventuras de Val, aparece el conflicto: es evidente que existía una política editorial por la que se pretendía

\footnotetext{
${ }^{11}$ Foster no solo consideraba que la rotulación era un arte en sí mismo sino que no debería de haber escisión entre texto e imagen, o como él mismo nos dice: "Las letras deben parecer grises cuando las miro de soslayo. Si percibes un área negra es que algo ha salido mal" (Kane. Op. cit.p. 128) la intención de Foster, por lo tanto, era que todo quedase armónicamente entonado, conformando una misma unidad visual.

${ }^{12}$ De hecho la primera propuesta de ese proyecto marcadamente personal de Foster, como se sabe, no será admitida por la United Feature Syndicate para quien estaba desarrollando Tarzán. Para esa nueva saga, además de contar con un protagonista heroico que no debía ser "un pomposo príncipe", Foster quería claramente situarla en un conciso momento histórico que además le permitiera libertad de creación si bien minuciosamente documentada y construida de manera verosímil.
} 
"elevar el nivel de calidad" de las tiras cómicas ${ }^{13}$ pero, aun con ello, la resolución de Foster sobre cómo narrar no podemos enmarcarla como fruto de una mera estrategia de mercado, en la que un gran ilustrador asume la tarea de relatar y por tanto, omitiendo muchos de los recursos propios del lenguaje de los cómics, utiliza la facilidad de la palabra para contar y el virtuosismo del dibujo para describir, a modo ilustrativo, lo dicho. Por contra, la creación de un relato extenso y complejo, de corte naturalista — un reto aún para el medio en aquellos momentos- alejado de las tiras cómicas ${ }^{14}$ es parte de su conflicto como narrador, como lo encontramos perfectamente esbozado en las palabras de Mark Schultz: ${ }^{15}$

Con las limitaciones de espacio que implica una tira cómica la información que se extiende por toda la secuencia necesariamente reduce la escala de la historia que se está contando. Uno no puede narrar una historia repleta de acontecimientos en el transcurso de tanto tiempo si decide emplear bastantes viñetas para relatar una sola acción, es decir, una parte característica de información. Del mismo modo, si se comprime mucha información en una viñeta se corre el riesgo de sacrificar cierta intimidad con las acciones del personaje y de perder de algún modo la fluidez narrativa.

\title{
Un similar argumento lo leemos también en palabras del propio biógrafo: ${ }^{16}$
}

\begin{abstract}
Debido a las limitaciones que le imponía el espacio, el texto y los dibujos debían avanzar juntos pero por separado. Explicar un solo dibujo era un esfuerzo inútil; así pues, Foster decidió intencionadamente narrar el espacio que había entre las viñetas. Se convirtió en la voz de los sentimientos de sus personajes e infundió a estos de vida y emociones con una prosa lírica y sencilla. Los personajes compartían secretos con los lectores y con nadie más, ni siquiera con los otros personajes de la página. Pensamientos ocultos, esperanzas, sueños de aventuras y sueños de amor fueron conocidos solo por unos pocos privilegiados que seguían lo que Hal calificaba como "romance ilustrado".
\end{abstract}

Paradójicamente será esa misma técnica narrativa la que lo inscriba como el padre indiscutible de la historieta de aventuras en la historia del medio. Toda una evidente contradicción

\footnotetext{
${ }^{13}$ Tal y como lo refiere Will Eisner: "En algún momento, a mediados de los treinta, los sindicatos de prensa decidieron que querían mejorar la calidad de sus cómics, así que contrataron a ilustradores como Alex Raymond. La idea era que entrase gente con calidad (...) Los sindicatos de prensa contrataron a grandes ilustradores. Hal Foster fue uno de ellos, Alex Raymond fue otro, y había algunos otros ilustradores, maestros del lápiz y la tinta, que fueron contratados para hacer tiras. La idea era: consigamos calidad. Su idea de calidad era que los dibujos fueran mejores”. En Eisner, W. y Miller, F. Eisner/Miller. Barcelona. Norma Editorial, Colección: Will Eisner n. ${ }^{\circ}$ 16, 2006.

${ }^{14}$ Contrariamente a la política editorial habitual por la que toda nueva serie debía pasar primero por el formato de publicación como tira diaria (dailystrip) para, una vez demostrado su éxito, saltar a las páginas dominicales ya bajo el formato del Sunday - a toda página y a color - Foster quiso lanzar desde el principio su nueva saga a página completa, uno más de los motivos de desacuerdo con la United Feature Syndicate [Cfr. Vázquez De Parga, S.: Harold R. Foster. Barcelona, Toutain Editor, Col. Cuando el cómic es nostalgia Vol. 3. (1983), p. 44-45]; de modo que El Príncipe Valiente aparecería publicado desde el principio en un gran formato, si bien y curiosamente lo haría primero en sábado (13 de febrero de 1937) —al igual que las siguientes 65 primeras planchas de la serie- y solo a partir del 15 de mayo de 1938 se convertiría en auténtico dominical.

15 Cit. en Kane. Op. cit. p. 204.

${ }^{16}$ Kane. Op. cit.p. 115.
} 

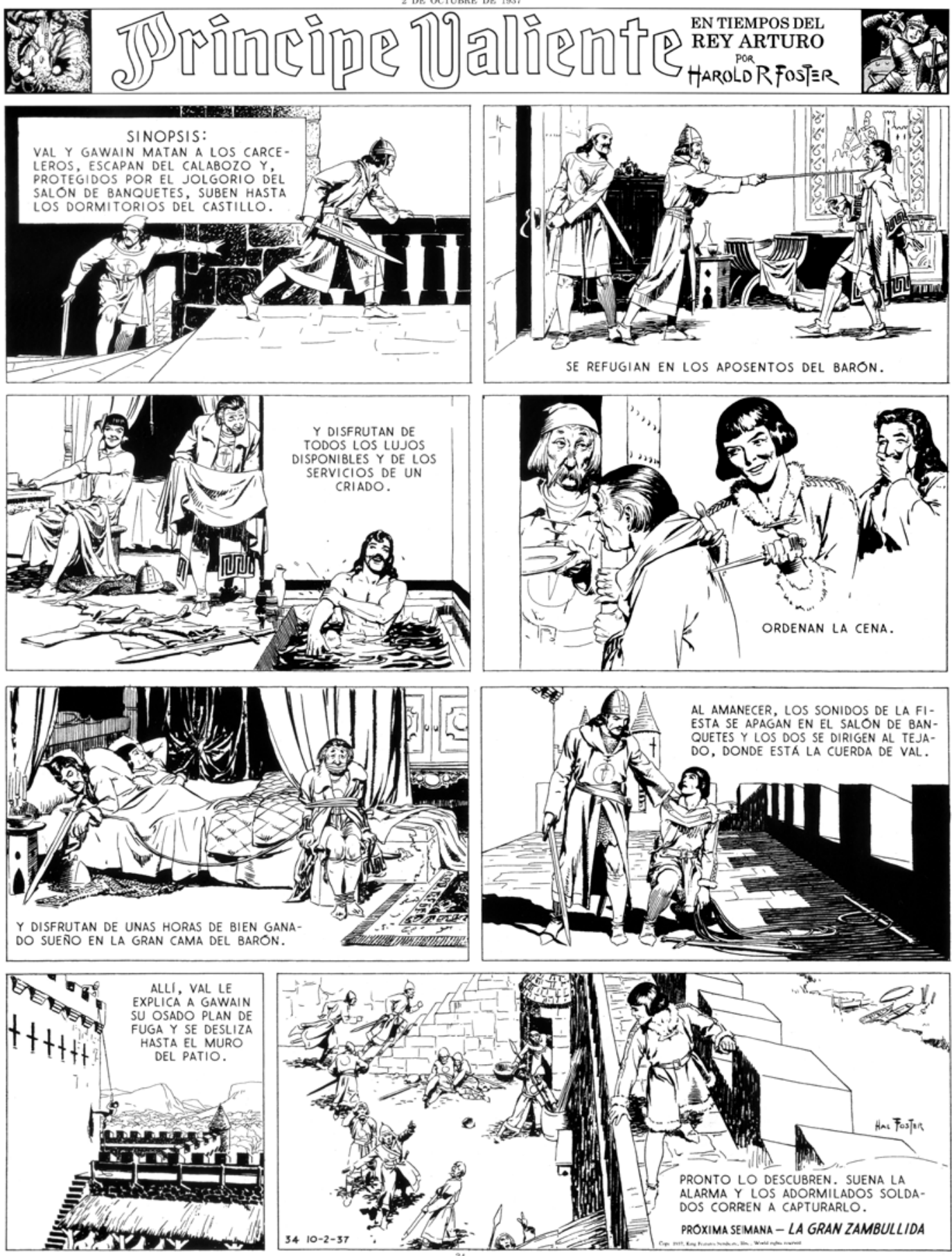

FIG. 4. Plancha n. ${ }^{\circ} 34$ (2 de octubre de 1937)

(C) King Features Syndicate, Inc. Fuente: Principe Valiente Vol.1: 1937-1938. Portugal, Manuel Caldas (Ed.) col. Livros de Papel, 2006. 
pues sin duda e irónicamente es al parecer el detalle y precisión de sus estampas ${ }^{17}$ lo que lo rechaza a la vez que lo sitúa como indiscutible maestro de maestros de la historieta. ${ }^{18}$ Todo ello hace que nos preguntemos ¿cuando se dice que Foster prescinde de muchos de los recursos propios del lenguaje de los cómics - tal y como lo manifiesta Salvador Vázquez de Parga—, ${ }^{19}$ qué es exactamente lo que se quiere decir?:

Las abundantes viñetas panorámicas de Prince Valiant suponen algo más, suponen en sí mismas una descripción del movimiento e incluso del sentimiento de los personajes que en ellas aparecen. Porque éste es el verdadero estilo narrativo de Harold Foster, un estilo personal y peculiar que prescinde de muchos de los recursos propios del lenguaje de los cómics, que incluye los diálogos en los imprescindibles textos, pero que enriquece éstos con imágenes espectaculares, rigurosamente documentadas, capaces de darles un sentido único, grandilocuente y total. Como contrapartida la visualización ha de ser detenida y minuciosa, pues sin duda una rápida lectura no permite captar la maravilla de la obra de Harold Foster.

Tras leer estos argumentos tal vez debamos preguntarnos cuáles son esos elementos necesarios de una narración gráfica para poder ser considerada como perteneciente al medio historieta, y vincularlo a las necesidades dramáticas de este autor. Recogemos para dar luz a esta idea la sucinta pero clarificadora descripción de Chatman: ${ }^{20}$

(...) cada narración tiene dos partes: una historia (histoire), el contenido o cadena de sucesos (acciones, acontecimientos), más lo que podríamos llamar los existentes (personajes, detalles del escenario); y un discurso (discours), es decir, la expresión, los medios a través de los cuales se comunica el contenido. Dicho de una manera más sencilla, la historia es el qué de una narración, lo que se relata, el discurso es el cómo. ${ }^{21}$

$\mathrm{El}$ acto narrativo es pues la forma por la que el lector se entera de lo sucedido, ya que un relato no es más que un juego de informaciones, revelaciones que se nos irán proporcionando por distintos medios, y es ahí donde entra en juego los procedimientos, la esencia y singularidad del lenguaje de las historietas. Seguir observando - al parecer un continuo tema de debate- solo la relación texto e imagen, ${ }^{22}$ es dejar de lado las operaciones de selección,

${ }_{17}$ Utilizo conscientemente esta denominación pues es así como muchos de sus admiradores perciben las viñetas de Foster, olvidándose que se trata de un sistema secuencial.

18 Tal y como lo resume el dibujante William Scout: "actualmente no existe ningún artista de cómic contemporáneo 'realista' que no haya recibido la influencia directa o indirecta del gran Harold Foster” en KanE. Op. cit., p. 206.

19 Vázquez De Parga, S. Op. cit. p. 55.

${ }^{20}$ Chatman, S. Historia y Discurso. Madrid, Ed.Taurus. 1990, p. 1920.

${ }^{21}$ La narratología estudia la forma narrativa sea cual sea su medio de expresión, no importa si se trata de un texto escrito, visual o audiovisual. La narración por tanto no hay que supeditarla a la palabra escrita, ni limitarla exclusivamente a la novela u otros géneros literarios.

22 Identificar y asociar el texto, las palabras escritas, con lo narrativo y los dibujos con lo descriptivo impide adentrarse en la observación del verdadero sistema narrativo de las historietas. No es momento aquí de desarrollar esta idea, pero sí queremos hacer hincapié en las tres condiciones esenciales — recogiendo lo aportado por Román Gubern - que permiten identificar al cómic como tal: "una secuencia de imágenes consecutivas para articular un relato, la permanencia de, al menos, un personaje estable a lo largo de una serie y - de haberlo- la integración del texto dialogado sincrónico a la acción representada en la viñeta”. Para un desarrollo 
dosificación y ordenación de la información sobre los acontecimientos que el autor realiza como acto de comunicación y su actualización por parte del lector, su saber sobre la historia, todo ello inducido desde el propio sistema narrativo del medio y desde luego estrechamente vinculado a la forma secuencial y altamente elíptica y peculiar de las historietas, la verdadera esencia de su lenguaje, en donde palabras e imágenes no son dos cosas independientes, sino una combinación.

Como ejemplo de esta idea, podemos ver -en la Fig. n. ${ }^{\circ} 4-$ el complejo juego con la información de las viñetas $1 .^{\mathrm{a}}$ a $6 .^{\mathrm{a}}$. En esta secuencia Foster propone un guiño a su lector, en tono burlón, mediante el relevo y contrapunto entre lo que dice el narrador y lo que sucede en la imagen: El significado final es un montaje de sentido, bastante irónico, producido por la peculiar relación establecida entre ambos.

Foster toma pues una decisión, poder contar mucha más cantidad de historia, fundiendo y sumando dos potenciales: por un lado la voz experta del narrador que le ayuda a concretar y así progresar rápidamente en la abundancia de sucesos representados, sin tener que demostrarlos ni dar mayores explicaciones. Ya que, confiados en él, el narrador nos expone, cuenta, analiza, ironiza y concluye sobre hechos y sentimientos, haciendo avanzar de este modo la trama. A lo que se suma toda otra serie de informaciones - y no solo descriptivas o ilustrativas - que se irán entrelazando con las anteriores y que se nos transmiten gracias a la observación y seguimiento de las peripecias de los personajes (siempre desde un "conciso" punto de vista sobre su actuación). Sin olvidar, todo aquello que ha sido omitido y elidido - también ocultado o demorado conscientemente- y que es evocado por este sistema tan elíptico de relato, propio de las historietas. Sin duda todas ellas son resoluciones enteramente narrativas, basadas de lleno en el singular lenguaje del medio.

Permítasenos aclarar estas ideas mediante un pequeño ejemplo ${ }^{23}$ elegido prácticamente al azar — vid. Fig. n. ${ }^{\mathrm{o}} 4$ y n. ${ }^{\mathrm{o}} 6{ }^{24}$ para poder evidenciar el hecho de que en las resoluciones discursivas de un "Foster-narrador" está implícito un perfecto manejo del sistema narrativo de este medio: en todas y cada una de sus estampas existe no solo una bella composición sino una precisa selección, ordenación y dosificación de la información. Fruto de ello serán unas composiciones inscritas en un sistema secuencial en las que tanto el instante representado como su organización visual son narrativamente significantes.

mayor de esta idea cfr. Segarra, M. Op. Cit. p.198.

${ }^{23}$ Se trata de las planchas n. 34 (2 de octubre de 1937) y n.o 35 (9 de octubre de 1937). Utilizaremos para ello la reproducción de la edición restaurada por Manuel Caldas y editada en Portugal, de la que solo se distribuirían en España (en 2006) sus entregas n. ${ }^{\circ} 1$ y 2. Se trata de una cuidada edición en blanco y negro y que como comenta Álvaro Pons — en su blog de referencia, La Cárcel de Papel一: "La edición de Caldas es un prodigio de rigurosidad, calidad y amor a la obra: gran formato en blanco y negro, con un cuidado trabajo de restauración, que ha devuelto a la obra su potencia y épica original" (en http://www.lacarceldepapel. com/2006/07/07/la-edicion-definitiva-en-castellano-de-principe-valiente/). Desgraciadamente un cambio en el contrato entre King Feactures Syndicate, Inc. y Caldas obligaría al editor a abandonar su distribución en España, a partir de la entrega n. ${ }^{\circ} 3$, para pasar exclusivamente por correo su venta. La versión inicial del presente texto, estaba prevista como prólogo de dicha entrega antes de este giro imprevisto.

${ }^{24}$ Una acción que se inicia en la viñeta $n .^{\circ} 7$ de la plancha 34 y recorre toda la plancha siguiente, la n. ${ }^{\circ} 35$ y cuya finalidad narrativa es contarnos como Val, una vez ha rescatado de su prisión a Sir Gawain, consigue fugarse del castillo junto a él. 
Veamos por ejemplo la viñeta n. 8 de la plancha 34 -Vid. Fig. n. 5 (drcha.) — en ella podemos observar cómo el punto de vista decidido por Foster fomenta el que su lector (modelo) reciba antes la información, viéndola/confirmándola con sus propios ojos, que dicha por el narrador. Así y cuando leamos la aseveración del narrador: "Pronto lo descubren, suena la alarma y los adormilados soldados corren a capturarlo" - un texto situado después, al final de la acción representada-, serán informaciones ya sabidas, descubiertas y deducidas por el lector gracias a la elección y decisión de ese conciso 'punctum temporis: $:^{25}$ Véase el soldado


FIG. 5. Viñetas 7 y 8, Plancha 34 (2 de octubre de 1937).

que señala a Val o el resto de la acción que se encuentra referida en ese instante preciso: un par de soldados subiendo ya las escaleras, otro saliendo de la torreta, etc. Por ello el texto de anticipo de la siguiente entrega - la gran zambullida - no hará más que confirmar aquello que ya intuíamos que podía suceder (anticipación) puesto que lanzarse por uno de los huecos de las almenas es la única salida que le queda a Val (anticipación que será confirmada en la siguiente entrega). Todo esto se nos muestra en un primer término muy escorzado, gracias a la elección de este conciso punto de vista la muralla conforma visualmente una potente diagonal que prácticamente escinde a la viñeta en dos partes. Pero observemos también el gesto de Val: pese a su situación de peligro, él está representado sereno, dejándose ver, sabiendo lo que quiere hacer, gestos que no pasan desapercibidos para el lector y que le ayudan a intuir que existe una premeditación, no en vano, si bien aún no lo sabemos todo, si estamos al corriente de que Val y Gawain están en plena ejecución de su osado plan.

La elección del punto de vista dentro de un sistema secuencial tan elíptico atañe pues al instante preciso en el que debe ser representada la acción y fruto de ello surge una composición singular en el que el orden de exploración (lectura) interno por la viñeta es significativo de cara a la elaboración y reconstrucción de la historia por parte de su lector.

Estas resoluciones narrativas, además de requerir que se determine y represente con precisión un instante - capaz de hacer evocar a su lector todo aquello que directamente no ha sido dicho o no será necesario decir-, también debe situar su mirada en un preciso lugar

25 Ampliamente teorizado si bien para la representación pictórica, supone la selección del momento que mejor permite reflejar un antes y un después en la escena representada. 


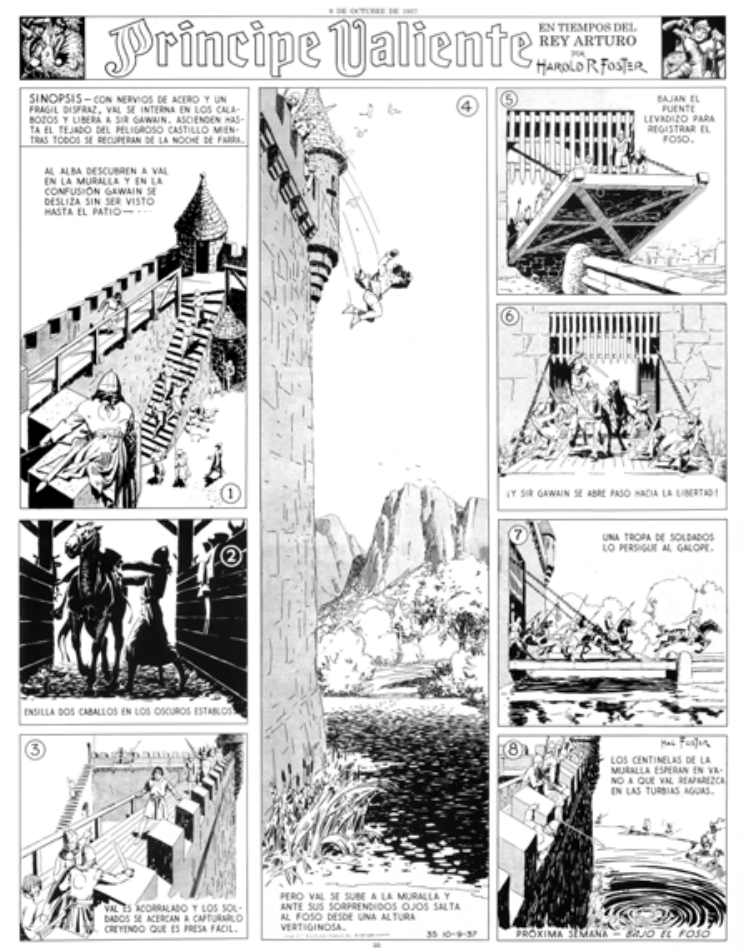

FIG. 6. Plancha n. 35 (9 de octubre de 37).

desde donde mirar la escena. Son determinaciones que influyen asimismo sobre lo que debe ser elidido entre una viñeta y otra. Veamos de nuevo esta idea con un ejemplo de la siguiente plancha 一vid. Fig. n. ${ }^{\circ} 6{ }^{2}{ }^{26}$ en la $1 .^{a}$ viñeta (Fig. n. $\left.{ }^{\circ} 7\right)$ y para que pueda suceder la necesaria acción paralela de Gawain, podemos ver como aquella acción principal de la entrega anterior - "Val es descubierto por los soldados" - pasa ahora, compositivamente, a un segundo término para así privilegiar la acción sobre Sir Gawain, dejando esa situación apurada de Val, no solo en profundidad sino también en un breve suspense. Gawain es ahora el sujeto protagonista de esta pequeña acción paralela: ${ }^{27}$ Aprovecha "la confusión" (V.1) para llegar a las cuadras (V.2) y poder completar así su parte del plan (V.6). Entre tanto y de nuevo se nos dirige y retorna sobre la acción inicial (V.3).

En las viñetas 5 y 6 - Fig. n. ${ }^{\circ} 8$ - se cierra pues aquello que el narrador no quiso contarnos en la viñeta 7 de la plancha 34: "El osado plan de fuga". La acción que nunca veremos de Gawain sucede asimismo en un tiempo omitido: El del intervalo entre las viñetas 2 y 3 de la plancha n. ${ }^{\circ} 35$, que tampoco se quiere representar para así lograr el efecto deseado en el desenlace del plan de fuga.

${ }^{26}$ En esta plancha podemos ver un interesante juego con el formato de la viñeta central gracias al cual se consigue expresar a la perfección la gran caida al foso pero también dilatar el tiempo, para permitir que transcurra "ese tiempo necesario" para que Gawain realice su parte del plan.

${ }^{27}$ La narración de acciones paralelas — ese fundamental mientras tanto- es dentro de la linealidad del relato, una de las más interesantes y complejas de resolver. Recordemos que había sido uno de los grandes retos ante los que tuvieron que enfrentarse los narradores visuales (tanto en el cine como en el cómic). 

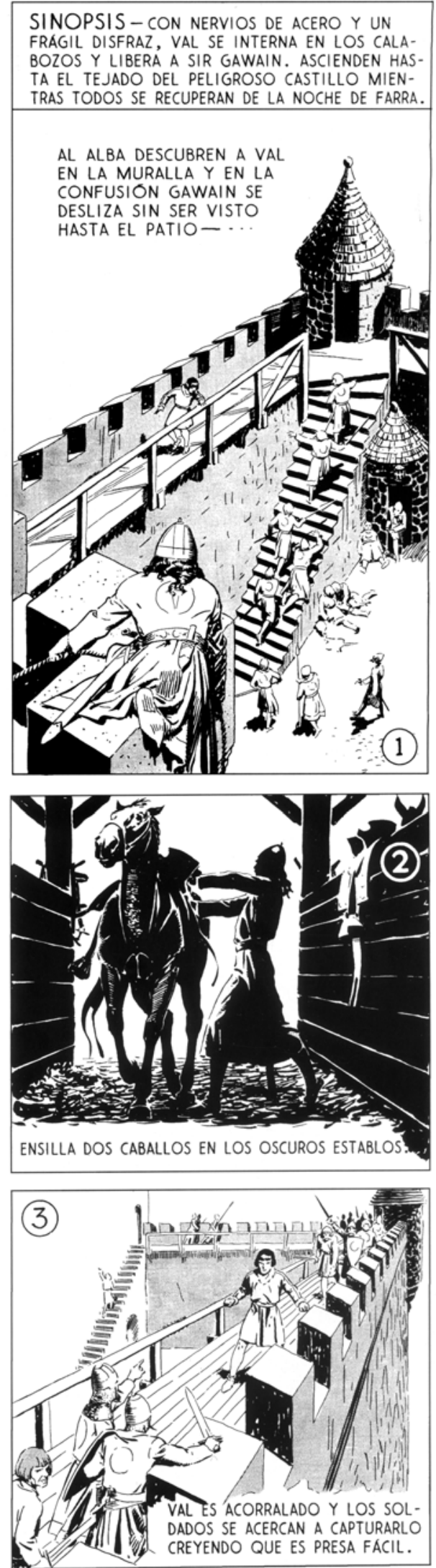


(Izquierda) FIG. 7. Viñetas 1-2-3 de la Plancha n. ${ }^{\circ} 35$.

(Derecha) FIG. 8. Detalle plancha n. 35 . 
Creemos que esta detenida descripción de una minúscula acción puede desmentir ese tópico de que la imagen reitera/ilustra lo que dice la palabra a la vez que confirma la idea del juego de dosificación de la información, las relaciones estructurales y funcionales entre todos los elementos y de que el sentido final es el resultado de su combinación, en sí, de un complejo "sistema".

Como vemos son decisiones todas ellas que atañen al acto de la narración y que gracias a ellas se nos irán revelando toda una serie de sutiles matices sobre los sucesos acaecidos buscando producir determinados efectos dramáticos en su espectador. La viñeta al ser obviamente un encuadre, sirve por tanto para mostrar, para dirigir nuestra atención sobre acciones concretas, pero también para ocultar, demorar o forzarnos a sobreentender lo no dicho. Es por ello que la composición de las viñetas están supeditadas a todo ello, de tal forma que el sistema de representación narrativo-visual de las historietas, pese a estar organizado para nuestra mirada, induce continuamente a que notemos que la nuestra es una mirada carente, impedida para poder verlo todo y es, gracias a ello, como el lector participa activamente en la construcción del sentido tanto de lo dicho como de lo "no dicho", de lo ausente: solo se nos permite ver determinadas situaciones y al encontrarse inscrita cada viñeta dentro de un sistema secuencial y altamente elíptico, la acción en ese universo ficcional debe seguir avanzando; de modo que al cambiar de viñeta, nos incorporamos como lectores/espectadores ante algo que ya está sucediendo, obligándonos así a tener que elaborar, deducir o sobreentender de nuevo todo lo omitido.

\section{El "Estilo Épico" de Foster}

En 1914, a sus 22 años, el autor inicia su profesión como dibujante en el departamento artístico de la "Bridgens Limited", Winnipeg (Manitoba, Canadá) un trabajo que se cruzaría casualmente en su camino. Fue en esa época cuando desarrollaría un excelente oficio gráfico y una gran destreza con la captación y representación del detalle y el realismo, asentando su poder de observación y creación de sutilezas en cada línea, que más adelante desarrollaría de un modo infinito. En el seno de esa inicial actividad como ilustrador para catálogos de ventas por correo de prendas interiores femeninas ${ }^{28}$ vivió inmerso en una atmósfera cargada de creatividad y no solo en el oficio gráfico, de hecho, el jefe de ese departamento Tom W. McLean, junto a otros artistas próximos a Foster, formaría el Grupo de los Siete (1920) quienes ayudarían a "trazar la dirección que tomaría el movimiento artístico canadiense de principios del siglo $\mathrm{xx}$ " ${ }^{29} \mathrm{El}$ estudio estaba pues lleno de prometedores artistas con intereses comunes. Más adelante seguiría inmerso en ese ambiente, puesto que, en paralelo a sus variados ejercicios profesionales, Foster se irá formando en diversas instituciones de arte.

Sin embargo y pese a que sus orígenes como dibujante suceden en un entorno apasionado por la representación gráfica y la expresión artística y visual, pasando por encima de su oficio, dominio y pasión como ilustrador, Hal Foster fue consciente de que la expresión

${ }_{28}$ No en vano era un requisito imprescindible la representación realista del detalle, ya que los clientes virtuales no querrían encontrarse con sorpresas una vez adquirida la prenda.

29 Kane. Op. cit.p. 23. 
narrativa era más importante que su propia inclinación por la imagen o como él mismo dirá "el dibujo de los cómics no es demasiado importante, pero la idea de la historia sí lo es. Una buena historia puede tener éxito aunque su ilustración sea mediocre. Sin embargo, un buen dibujo no puede sostener una historia mediocre." ${ }^{30}$

Foster, preocupado por la naturaleza narrativa de la historieta, cuando define su obra lo hace bajo la calificación de "romance ilustrado" pero el error es considerar que esta definición tiene que ver solo con la utilización de la palabra escrita. Por el contrario se trata de una evidencia sobre su intención de aproximarse a las narraciones medievales por excelencia, al género de la novela de caballerías ${ }^{31}$ propia de los siglos XIII al XVI, y por tanto, a un estilo narrativo adecuado a los contenidos de procedencia Artúrica, o la llamada Materia de Bretaña. Un género totalmente en coherencia con la época que Foster quiere poner en escena, o como lo expresa Marín: ${ }^{32}$

Lo que Harold Foster tiene claro desde el principio, algo que sus detractores no son capaces de comprender, es la manera en que quiere contar su historia. Foster sabe que la narración épica que emprende en 1937 tiene que narrarse desde la épica, y la épica es palabra escrita y antes fue palabra oral. Para contar lo que Foster quiere desde otra óptica (un imposible) haría falta en cualquier caso muchísimo más espacio narrativo del que emplea (...) Foster obvia el bocadillo y trabaja el texto de forma que dibujo y narración se complementen y ayuden a avanzar la trama, desarrollándola de la única manera posible en que ésta puede ser desarrollada, con el tempo tan característico de la serie, y es el texto (poético pero sencillo) lo que permite enganchar con la historia y conectar con los personajes.

Sumándome al argumento de Marín coincido en pensar que la decisión de acogerse a este género es lo que hace que en la obra de El Principe Valiente forma y contenido queden entretejidos, si bien yo no limitaría a la palabra escrita como único vehículo de lo narrativo.

La épica es pues una de las claves para poder entender la decisión de Foster sobre la utilización de la presencia de la voz del narrador como conductor para su relato con tono y estilo medieval, buscando con ello la equivalencia con el conjunto de correspondencias y reglas - según el imaginario colectivo- que explican este código cultural. En el relato épico, si atendemos al género literario, sus autores presentan de forma aparentemente objetiva ${ }^{33}$ hechos legendarios desarrollados en un tiempo y espacio con apariencia histórica. Es por ello que en este tipo de género literario los escritores usan como forma de expresión habitual la narración conducida por una voz de un narrador que todo lo sabe, incluso lo que piensa y siente su protagonista, y por tanto, capaz de objetivar y legitimar lo sucedido. En las novelas

\footnotetext{
${ }^{30}$ En una carta dirigida a Victor Rally el 24 de febrero de 1969. En Kane. Op. cit. p. 115.

${ }^{31}$ Haciendo una precipitada definición, las novelas de caballerías son narraciones medievales publicadas en los primeros años de la imprenta, que tienen por objeto la exaltación de un héroe y sus vicisitudes y así divertir relatando las hazañas y aventuras a veces inverosímiles de esos héroes legendarios e invencibles. Como dice Edwin Williamson: "Precisamente la novela artúrica es patrón y fuente de la ficción caballeresca" (en El "Quijote" y los libros de caballerías, Madrid, Taurus, 1991, p. 20). Género que Foster conoce perfectamente, un hecho que ha sido explicado por distintos autores al referir su pasión por la lectura histórica.

32 Ibid.p. 44.

${ }^{33}$ Mediante esa voz típicamente distante (narrador en tercera persona) que es la esperable en la épica.
} 
épicas aparece también la descripción ${ }^{34}$ y el diálogo pero usualmente estará siempre representado de modo indirecto.

Aunque esta será una elección consciente por parte de Foster y no una mera fórmula comercial por cuanto "la forma debe resultar de una exigencia del contenido; es un molde que se moldea y no que moldea", ${ }^{35}$ las historias de Valiant son también algo más que el relato de un universo coherente sobre la épica Edad Media, pues el referente de Valiant no es tan solo la medievalidad, son también los ideales y la propia mirada (conciencia) de un autor que toma prestado el contexto medieval para adoptar un punto de vista sobre la conducta humana y sobre posibles modos de vida. En sí, El principe Valiente es la construcción de un universo verosímil pero desde la visión de Hal Foster y de ahí la elección del tema, tiempo y lugar sobre los que él quiso situar su proyecto personal y en cuya materialización aparecerá a veces transfigurada como historia Artúrica la esencia de la 'vida-viaje'/ 'vida-aventura' del propio Harold Rudolf Foster.

Tal vez sea esto lo que podría llegar a explicar no solo muchas de esas licencias históricas que a menudo le han sido criticadas, sino también dar luz sobre esa necesidad de manifestarse a través de su relato, apareciendo su conciencia como autor trasfigurado en el papel de narrador. Pero, y como también lo expresa Oscar Tacca: ${ }^{36}$

El narrador no es simplemente el autor: su misión es más precisa: contar (...) "el autor no es, naturalmente, el hombre, pero tampoco simplemente el hombre escribiente, la diferencia no es otra que la que va del hombre práctico a la del hombre que escribe (...) un hombre de oficio acuciado por el afán de crear y, sobre todo de haber creado. Un mundo, o tan siquiera una comarca. (...) La categoría de 'autor' es la del escritor que pone todo su oficio, todo su pasado de información literaria y artística, todo su caudal de conocimiento e ideas (no solo las que en la vida sustenta) al servicio del sentido unitario de la obra que elabora.

Y es gracias a esa cautivación del relato sobre su autor, como podemos acceder a su propio conocimiento reflexivo sobre las cosas $-\mathrm{y}$ que se pone a la vista su mirada sobre los personajes, sus actos o sus dudas con esas adjetivaciones, solo posibles usando la voz del narrador...- Tal vez encontremos en ello la clave de por qué El Príncipe Valiente se ha convertido en una obra inmortal.

Esa necesidad de manifestar su mirada, le impulsó a decidir su concisa técnica narrativa: Foster nos propone pues un "punto de vista", nos revela con la voz de su narrador sus ideales, su visión de las relaciones humanas, lo que sin duda tuvo claras consecuencias a nivel de acto

\footnotetext{
${ }^{34}$ Lo épico, en Foster, también lo encontramos por la cantidad de detalles, su precisión en la descripción de un mundo en el que un árbol de Foster, nunca es un árbol cualquiera en genérico, sino ese conciso abeto. Así también en cómo queda representado el tiempo en determinadas viñetas, un tiempo - materia esencial de lo narrativo- que transcurre y que es sugerido por la propia descripción de la acción, o como nos dice Schultz: “El modus operandi característico de Foster reside en el uso 'épico' de las viñetas, con unidades específicas de información que transmite en una única viñeta, lo cual le permite narrar 'grandes historias'.” Cit. en Kane. Op. cit. p. 204.

35 Pouillon, J. Temps et roman, Gallimard, Paris, 1946, p. 14.

36 TAcca, O. Las voces de la novela. Madrid, Ed. Gredos, 1978, pp. 17-18.
} 
narrativo, sacando a la luz una serie de contradicciones con el lenguaje normalizado de las tiras cómicas, haciéndoles frente mediante la invención de un estilo propio de narración que combinaría todas estas sinergias, algo que trataremos de abordar a continuación.

\section{Mirada, CONCIENCIA Y VOZ: \\ SOBRE EL AUTOR Y EL NARRADOR DEL RELATO.}

Podríamos decir, sin creer que erramos demasiado, que el sentido de la vida en Foster y el acto de creación acabaron confundidos en la ficción apareciendo - como huella de su autor- la necesidad de manifestar esa conciencia que es el narrador del Príncipe Valiente. El propio Foster dirá por sí mismo:

“E1 Príncipe Valiente se convirtió en algo más que un personaje, alguien a quien conocía personalmente; sabía todo lo que podía hacer. Se queda detrás de mí cuando escribo y cuando hago algo que no es propio de su personaje, aunque no puedo verlo, sé que se niega con la cabeza. Es muy duro manejar a un héroe como el Príncipe Valiente (...)". ${ }^{37}$

Así y como acertadamente escribe W. Kayser ${ }^{38}$ "el autor crea el mundo de su relato; pero también ese mundo se crea a sí mismo a través de él, le transforma en sí mismo, le obliga a entrar en el juego de las transformaciones para manifestarse mediante él" esta cita puede revelar ciertas cuestiones, aún latentes, que a nuestro modo de ver sitúan y cierran perfectamente tanto la elección del tema para la creación de esa obra personal que abarcaría prácticamente toda su vida de edad adulta y la elección premeditada de la voz del narrador. Ello mismo también aclara muchas de las voces críticas que se han escrito, sobre la aparente ausencia de veracidad sobre la medievalidad en las historias de El Principe Valiente — si bien, para nosotros, y por tratarse de una obra de ficción, son críticas que no creemos que deban tener relevancia de cara a desmerecer la calidad de la obra de Foster, ya que lo importante en toda obra de ficción es la verosimilitud interna, la lógica que se establece a través el propio relato- Así creemos que el verdadero referente de Valiant no es desde luego la medievalidad: el relato de $\mathrm{Hal}$ Foster es el de la construcción de un universo verosímil desde los ideales y la mirada (conciencia) del autor y su visión del mundo.

Y es este un argumento fundamental para establecer la necesidad de oír la voz de Foster-narrador, y lo que permite dar luz a el por qué encontramos versiones tan enfrentadas sobre este tema: las incoherencias entre la historia de El Principe Valiente y su fidelidad a lo sucedido en la Edad Media ${ }^{39}$ o la idea opuesta: "son personajes con vida propia y que reflejan

37 KANE. Op. cit.p. 84. Al respecto es muy reveladora la ilustración del propio Foster al respecto, vid. Fig. n. 9.

38 En el capítulo "Actitudes y formas de lo épico" de su libro: Interpretación y análisis de la obra literaria. Ed. Gredos, Madrid. p. 468.

39 Así Ana Garrafón en su artículo sobre "La Edad Media y los peregrinos en la Literatura infantil y Juvenil" (Alicante, Biblioteca Virtual Miguel de Cervantes, 2004) comenta, a propósito de las explicaciones sobre El Príncipe Valiente dadas por Sergi Vich en su Historia del cómic (Barcelona, Glénat, 1997): "(Sergi Vich) aporta una visión crítica con detalles de las incoherencias temporales y espaciales del famoso cómic. Personajes y objetos reales y ficticios pertenecientes a distintas épocas se mezclan sin reparo, y muestran, por ejemplo, a 


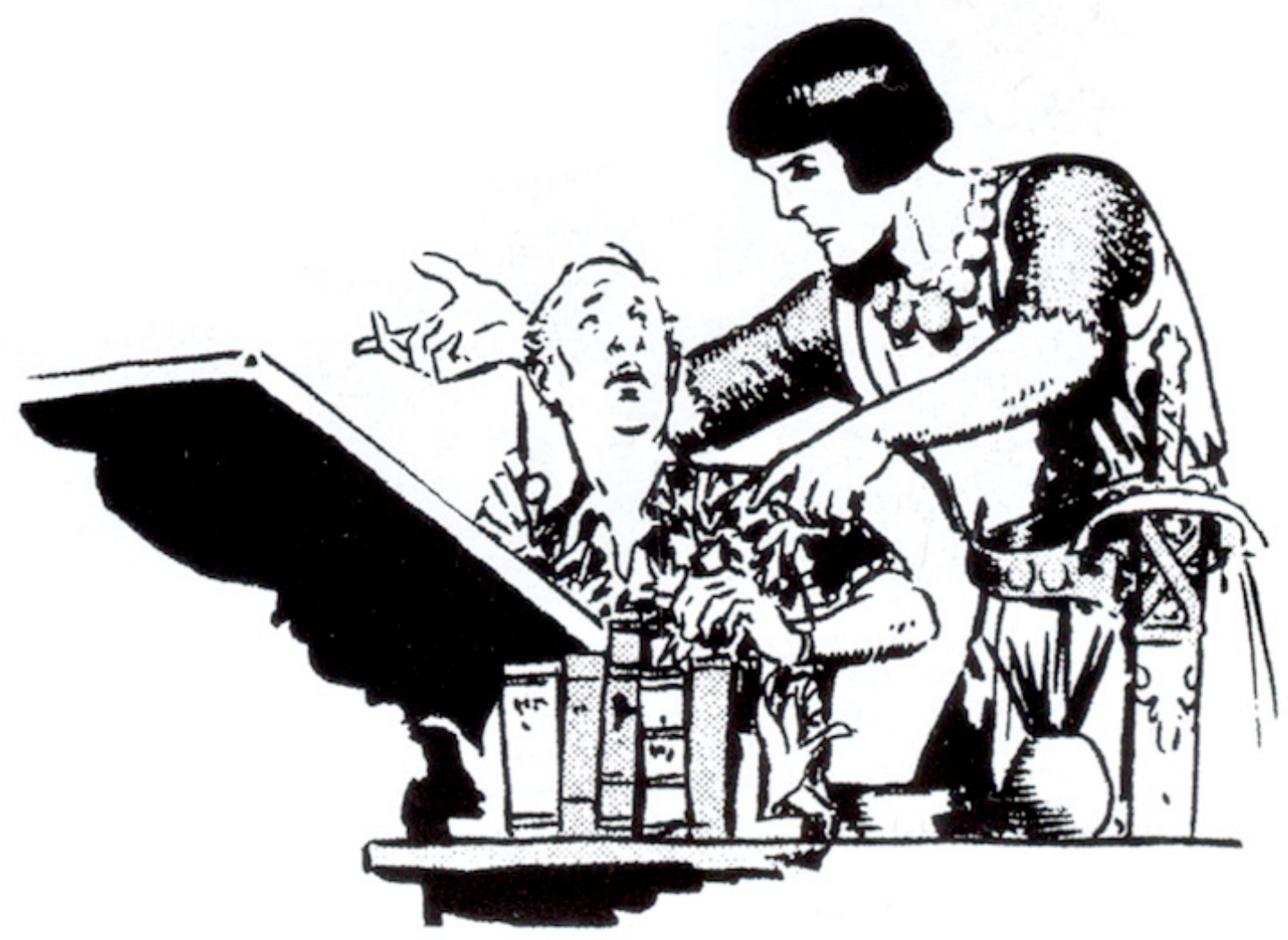

FIG. 9. Ilustración de Hal Foster. Fuente: Kane. Ibid., p.117.

su época con exactitud”. ${ }^{40}$ En realidad creo que podríamos decir que las aventuras artúricas, son historias vividas por Foster y no en un sentido biográfico sino experimentado, es decir basado en un conocimiento personal de la propia aventura como vivencia ${ }^{41} \mathrm{y}$ adquirido por las peculiares circunstancias y situaciones personales de Foster. Harold Foster sin duda no es Valiant, pero de todos es conocido que tuvo una vida cargada de experiencias algo extremas, de aventuras inmersas en plena naturaleza, con seguras situaciones inciertas y no carentes de riesgos. ${ }^{42}$ Estamos convencidos de que el amor, el valor, el honor, la amistad, en el sentido

caballeros más cercanos a la leyenda que a la realidad, que portan arneses militares propios de los siglos XIV y XV con lanzas de torneo, cotas de malla, cascos cerrados y testeras para sus monturas de épocas posteriores. También los nobles son presentados como burgueses renacentistas, en castillos de corte más oriental que europeo, que presentan a ojos de un historiador un anacronismo y mezcla de estilos sin duda insoportable". En "La Edad Media y los peregrinos en la lij: una aproximación”. España: Biblioteca Virtual Miguel de Cervantes, p. 27. Disponible en línea en $<$ http://www.cervantesvirtual.com/obra-visor/la-edad-media-y-los-peregrinosen-la-lij---una-aproximacin-0/html/fff75aa2-82b1-11df-acc7-002185ce6064 3.html>.

40 "Harold Foster has created living characters that reflect their epoch faithfully". BeCKer, S.D. Comic Art in América. New York, Simon and Schuster, 1959, p.234.

41 O como dirá Rafael Marín: "la vida y la obra se explican la una a la otra" —Cfr. con lo expuesto por el autor en Op. cit. pp. 5 a 12.

42 Se convierte en algo casi mítico, el evocar su viaje en bicicleta desde Canadá, su país natal, hasta Chicago, o bien pensar en el poso vivencial que tendría el autor como fruto de sus frecuentes inmersiones en plena 
común esencia de lo Artúrico y de la Medievalidad, son también esencia de la propia visión de la vida y de la ética de Foster:

Esta es tu vida, Hal Foster le dedica Ralph Edwards como epitafio al "príncipe de los Ilustradores". Con una pluma de artista como lanza y una tabla de dibujo como escudo, has mostrado a los hombres las cualidades de un caballero de los viejos tiempos. Que tú y tu Príncipe Valiente podáis vivir durante mucho tiempo para hacer que el valor y el honor sigan brillando en nuestros corazones.

Y junto a toda una serie de "argumentos robados" como el propio Foster dirá sin tapujos a James Branco Cabell, Haldane MacFall o Edgard Plunkett Dunsany, tres de sus autores favoritos, o a Cecilia Holland ya que "pasaba horas, días leyendo" aparece la materia de la que Foster en realidad quiere hablarnos como le dice en una carta a Milton Caniff: ${ }^{43}$

Me gustan las novelas históricas que no dan especial importancia a las fechas y a los lugares, ya que puede que no siempre sean correctas, pero te proporcionan muchos conocimientos. Todo lo que leo va a parar a El Príncipe Valiente, todo lo que puedes encontrar en él forma parte de lo que he leído - y concluye - Por lo tanto muchas de mis desgracias han sido de provecho. ${ }^{44}$ Cuanto más aprendo de los tiempos del Rey Arturo, menos pienso en nuestra civilización moderna. A decir verdad, la vida era a veces cruel en aquella época, pero era una brutalidad honesta. Al menos no lo justificaban con tantos tópicos virtuosos como hacemos en la actualidad.

En esta carta a Caniff aparecen de nuevo indicios de gran interés, así y tras relatarle sus idas y venidas a bibliotecas universitarias y museos en busca de documentación, Foster le comenta:

me tomaba un gran trabajo de varios días conseguir un solo dato. A pesar de todo, yo había almacenado una gran cantidad de información interesante y no escrita. Esa belleza de haber tenido que enfrentarme al frío mundo a la edad de $13 \operatorname{años}^{45}$ y de que se te haya negado una educación... conseguirla se convierte en un interesante juego que mejora a medida que pasa el tiempo. Si vas acumulando aquí y allá, al juntarlo todo, puedes convertirlo en algo.

naturaleza a lo largo de incontables días de caza, supervivencia y rotundo enfrentamiento con lo esencial. O el propio punto de giro de su vida, a la temprana edad de 13 años, fruto del azar —o como lo expresa Kane (Op. cit. p.16) - "por una extraña jugada del destino, es posible que el hecho de arruinarse y haber tenido que dejar Halifax les hubiera salvado la vida" al evitar que su familia se viera inmersa en los trágicos sucesos acaecidos en 1917 en esa pequeña ciudad costera donde había nacido Foster, con el resultado de la destrucción de casi la totalidad de la ciudad, fruto de la devastadora explosión del carguero francés SS Mont Blanc y un largo etcétera.

43 Cit. en Kane. Op. cit. p. 81.

44 El subrayado es nuestro.

45 El subrayado es nuestro. 


\section{LA CLAVE DEL DEBATE: \\ RELATO, NARRACIÓN Y VOZ.}

Muchos de los argumentos anteriores, aparentemente no hacen sino redundar sobre la tensión literaria existente en la obra de Foster, puesto que frente al relato literario en el que "el autor da la palabra a un narrador, y este eventualmente, a sus personajes (...) por mucho que se diferencien las voces, el narrador permanecerá siempre en el primer plano de la audición y de la conciencia". ${ }^{46}$ Por el contrario, en las artes escénicas (teatro) "el dramaturgo nos dice esto sucedió así: dos puntos y se levanta el telón apareciendo los actores con su diálogo como realidad primaria" al igual que en las artes narrativas gráficas y audiovisuales (historietas, animación y cine) que presentan la historia exponiéndola ante nuestros ojos ${ }^{47}$ como si sucediera en ese momento, de modo que es su espectador/lector quien presencia, concluye y explica la evolución y desarrollo de las acciones que van conformando, secuencial y elípticamente, el universo de la ficción: bajo esta técnica de exposición el diálogo, necesariamente, debe ser también puro.

Al situarle ante la propia acción de los personajes, la intervención de la mirada (y por supuesto la perspicacia) del lector/espectador en la reconstrucción de lo que está sucediendo permitirá (aparentemente) que sea innecesaria la presencia de un narrador que le explique los acontecimientos, pero también hará que paulatinamente sea más imperceptible el propio acto narrativo.

Observemos sin embargo que se trata de un narrador que en realidad no ha desaparecido, más bien ha conseguido permanecer convenientemente "oculto" tras los personajes, pues se trata de un específico sistema de representación narrativo que tan solo pone a la vista aquello que debe verse, enseñándolo o señalándolo para así poder revelárselo a su lector: un sistema de mostración que oculta sus propias huellas de producción y que supondrá el fundamento del lenguaje narrativo de las imágenes de los siglos xx y xxi, descubierto y desarrollado tanto por el cine, la animación o las historietas.

En el seno de ese proceso de invención y evolución de las estrategias y técnicas narrativas de estos medios, sucederá asimismo una peculiar aproximación de la prosa a la imagen ${ }^{48}$ que afectará de lleno al papel del narrador de las obras literarias y teatrales (novela victoriana, melodrama, folletines, etc.) promoviendo la paulatina desaparición de, hasta ese momento, ese papel omnisciente de su narrador o como lo describe Oscar Tacca: ${ }^{49}$

El examen y rechazo de la omnisciencia llevaron a la reflexión sobre la perspectiva y la adopción de un punto de vista determinado, este se resolvió casi literalmente en lo que su nombre indicaba,

46 TACCA. Op. cit., p. 22.

47 A diferencia de lo que ocurre en literatura, el punto de vista en el cómic o en el cine tiene un primer sentido no metafórico. Es un punto de vista óptico —el lugar de emplazamiento de la cámara — o de representación gráfica de un fragmento de la realidad y desde el cual se le permite ver al espectador.

48 Cfr. Fell, John L. "Espacio tiempo y prosa victoriana” en El filme y la tradición narrativa. Buenos Aires, Ed.Tres tiempos, 1977, p.77-114.

49 Op.cit. p. 27. 
es decir en la elección de un ángulo de enfoque, que excluía de las posibilidades del narrador la referencia de todo aquello que escapara a su visión (...) No es pues extraño que, como reacción, la novela se ciñera al punto de vista. Ni que su lenguaje se restringiese en consecuencia al mundo de lo visual (...) atenerse estrictamente en el relato a lo que verían nuestros ojos. No es extraño que, en un momento dado haya sido el arte de la imagen, el cine, quién mayor influencia ejerciera sobre la novela.

Creemos que del mismo modo la inclusión de bocadillos en el medio historieta fue también el efecto y no la causa central del hecho narrativo de este medio. Un efecto fruto de esa corriente de naturalización de todo relato. Así, en el relato gráfico, el estilo narrativo desarrollado a partir de la intervención de las voces directas de los personajes está en relación, como hemos dicho, con la evolución de los lenguajes de mostración, pues al focalizar sobre los personajes, estos aparentemente cobran independencia del narrador-explicador de tal modo que las apelaciones cooperativas del texto a su lector/espectador se realizan a partir del seguimiento de lo que el protagonista y el resto de personajes hacen, ven o dicen.

El lector de historietas recompone lo sucedido en ese mundo ficticio a partir de las informaciones que se hayan repartidas y dosificadas hábilmente entre los distintos recursos narrativos que posee el medio, entre ellos, quizá el más importante, el montaje de planos. De modo que con la aparición de los medios icónico-narrativos (cine e historieta) y la creación y evolución de un lenguaje propio de cada cual, será necesario transitar el relato para poder conocer la historia: toda una verdadera revolución del lenguaje de la imagen y en cuya base se encuentra la secuencialización, y fruto de ella, la significación surgida a partir del orden de exploración de las viñetas - tanto interna como a través de la linealidad de su disposición en la página. ${ }^{50}$

Entonces ¿qué es lo que distancia al Príncipe Valiente de las historietas —si es que lo hace-? o ¿qué es lo que distancia a la narración de Príncipe Valiente de la novela, como forma ficcional literaria por antonomasia? Si en las historias del Principe Valiente el texto escrito nos propusiera una continua aclaración de lo mostrado, explicándonos lo que vemos, es evidente que no solo existiría un acto de redundancia manifiesto sino, perfectamente, podríamos prescindir de las imágenes ¿por qué sin embargo — y más allá de su maestría gráfica一, estas pasan a ser algo verdaderamente representativo de Foster, reconociéndolo como el maestro del género de aventuras de este medio?. En realidad el problema no es que el texto repita lo mismo que se ve en el dibujo o que explique muchas más cosas que no se ven en los dibujos y la viñeta ilustre una sola de ellas -ideas que podemos encontrar demasiado a menudo como crítica al estilo narrativo de Foster-, se trata sin embargo de un sistema, una estructura con múltiples elementos entrelazados, cuya función —enteramente orgánica - es la de darnos a conocer la historia. De modo que para entender realmente la técnica narrativa de Foster hay que centrarse en analizar, no solo qué es lo que cataliza y aporta la información en cada momento, sino cómo ello se imbrica conformando una significación unitaria, mucho más rica que la información que recibiríamos por separado de la imagen o de la palabra.

50 Para una profundización sobre este tema véase Segarra, M. Op. Cit. pp. 195-221. 


\section{Conclusiones}

El camino de la naturalización de la voz de los personajes por la convención y el empleo del código de los bocadillos fue uno, otro sería el seguido por Foster quien haría uso de los hallazgos propios del sistema de "mostración" ${ }^{51}$ y de los juegos informativos y recursos múltiples que le aportaba la utilización de las diferentes voces escritas y su interacción con los elementos expresivos propios del lenguaje de este medio. Si bien, y contrariamente al comentario generalizado de que Foster evita los bocadillos de diálogo a favor de la cartela rectangular, pensamos que el autor crea variados recursos en el texto escrito, bastante más sutiles que la simple cartela del narrador-explicador, tratándose de un elemento peculiar de su lenguaje que el autor utiliza para inscribir diferentes y variadas voces para apoyar la construcción de su discurso bajo la clave de un género. Si observamos detenidamente las planchas originales,$^{52}$ el texto escrito acoge no solo la voz omnisciente del narrador, si no la introspección y el pensamiento de sus personajes, los diálogos indirectos, pero también sus diálogos directos o locuciones sin ningún mediador, siendo las comillas un código metafórico al igual que los característicos globos de diálogos y pensamientos, en los que sin duda existe una mayor naturalización, pero en ambos casos existe una convención representativa. En última instancia el acogerse a un género que le iba a permitir la expresión más íntima de sus ideales, al tiempo que creaba un universo de ficción fue una decisión meditada y consciente por parte del Foster-narrador y es ello lo que hace que en la obra de El Principe Valiente forma y contenido queden entretejidos.

Solo me queda decir, siendo consciente de que aún queda un largo camino para poder deconstruir el tópico, que "nuevas formas revelarán en realidad nuevas cosas" ${ }^{33}$ (Michel Butor): ¿Estamos seguros que encontraríamos ese infinito caudal de formas, imaginería e imaginación, si Harold Foster no nos hubiera relatado de ese modo tan genuino la historia de su Principe Valiente?

51 Insistimos, para nada patrimonio exclusivo del cine, sino del enfrentamiento de las imágenes ante lo narrativo o como lo expresa Pierre Couperie: "Los dibujos animados, las películas cinematográficas y las historietas nacieron simultáneamente; si bien cada una aparecía como independiente de las demás, encarnaban en tres formas relacionadas entre sí la tendencia única tan profundamente arraigada en el siglo xx". Al respecto recomendamos la lectura del capitulo del libro de John L. Fell: "Señor Griffith, le presento a Winsor MacCay". Op.cit. pp. 115-138.

52 Desgraciadamente se hace difícil su estudio, por el tratamiento que se da al texto escrito en las diferentes ediciones. Precisamente la, a veces, perceptible no unicidad entre texto escrito e imagen en las viñetas de El Príncipe Valiente es un desgraciado fruto de la publicación, son los editores quienes no han respetado - y tal vez, en ocasiones, fomentado su extrema escisión - ni el concepto de tipografía elegida por Foster, ni la entonación gráfico-visual del texto escrito para conseguir la graduación de los valores tonales en la viñeta y obtener así un efecto armónico en relación a la imagen. En muchas ocasiones tampoco se ha respetado, el lugar asignado por Foster para las palabras dentro de cada viñeta, perdiéndose asimismo, algo bien importante, el código de representación de todas las voces de su relato.

53 Cit. por TACCA, O. Op. cit. p.10. 


\section{Bibliografía}

Becker, S.. Comic Art in América. New York, Simon and Shuster, 1959.

Chatman, S. Historia y Discurso. Madrid, Ed. Taurus. 1990.

Eco, U. Lector in fabula. La cooperación interpretativa en el texto narrativo. Barcelona, Lumen, 1993.

Eisner, W. y Miller, F. Eisner/Miller. Barcelona. Norma Editorial, Colección: Will Eisner n. ${ }^{\circ}$ 16. 2006.

Fell, J.F. El Filme y la tradición narrativa. Buenos Aires, Ediciones Tres tiempos. 1977.

Marín, R. Hal Foster. Una épica postromántica. Madrid, Ediciones Sinsentido. 2004.

Kane, B.M. Hal Foster. Prince of Illustrators Father of the Aventure Strip. Vanguard Productions Press. 2001.

KaYser,W. Interpretación y análisis de la obra literaria, Madrid, Ed.Gredos. 1961.

Segarra, M. "La mirada del lector y el devenir del relato gráfico." En Quaderns de filología. Estudis de Comunicació, n. 3 (2008), pp. 195-221.

TAcca, O. Las voces de la novela. Madrid, Ed. Gredos. 1978.

Vázquez De Parga, S. Harold R. Foster. Barcelona, Toutain Editor, Col. Cuando el cómic es nostalgia Vol. 3.1983.

VICH, S. La bistoria en los cómics. Glénat. Barcelona. 1997. 